\title{
Intersections of Empire, Post-Empire, and Diaspora: De-Imperializing Lusophone Studies
}

CRISTIANA BASTOS

Universidade de Lisboa

\begin{abstract}
The present article opens with a generic plea for the de-imperialization of Lusophone studies. A de-imperial turn should allow researchers to explore more thoroughly the experiences of diaspora and exile that an empire-centered history and its spin-offs have obfuscated; it should also help to de-essentialize depictions of Portuguese heritage and culture shaped by these narratives. Such a turn promises to address the multiple identifications, internal diversities, and racialized inequalities produced by the making and unmaking of empire. My contribution consists of a few ethnographic-historic case studies collected at the intersections of empire, post-empire, and diaspora. These include nineteenthcentury diasporic movements that brought Portuguese subjects to competing empires; past and present celebrations of heritage in diasporic contexts; culture wars around representations; and current directions in post-imperial celebrations and reparations.
\end{abstract}

Keywords: Portugal, de-empire, plantations, labor, migrations, heritage

I make a plea in the present article for the de-imperialization of Lusophone studies. I suggest that expanding our scope beyond the geographies of the Portuguese empire will enrich and rescue some of the current discussions on identity and heritage, tradition and change, centrality and peripherality, dependency and development, racism and Lusotropicalism, gender, generation, as well as other issues. 
The shape and shadows of empire have powerful afterlives. In spite of the literature that addresses the centrality of migration, displacement, and exile in the overall experience of being Portuguese, mainstream representations of Portuguese identity are, to this day, dominated by evocations of empire- - be it through the theme of discoveries or through variations of Lusotropicalism. ${ }^{1}$ National celebrations more often pick icons like caravels and world maps than acknowledge the dispersion of its own emigrants or the internal diversities and inequalities created by empire.

The termination of the Portuguese empire in the 1970s did not erase its phantasmatic presence, whether within nostalgic or anticolonial milieux. Its map is replicated in the imagined community of Lusofonia or CPLP (for Comunidade dos Países de Lingua Portuguesa), which includes the nations, citizens, and residents of Portugal, Brazil, Angola, Mozambique, Cape Verde, São Tomé, Guinea-Bissau, East Timor, and some putative strategic partners that have entered CPLP regardless of language.

The shape and shadows of empire also affect scholarship. When scholarly critical analyses of the Portuguese empire were still sparse (Alexandre and Dias; Bethencourt and Chaudhuri; Henriques), and there was a chronic absence of Portuguese-related data in novel approaches to colonialism (Cooper and Stoler), some Portuguese and Brazilian anthropologists and historians attempted to innovate by cross-analyzing their work on empire and diaspora (Bastos, Almeida and Feldman-Bianco); yet their frame of reference remained within pre-defined geographies: Portugal, Brazil, Angola, Goa, East Timor, etc. ${ }^{2}$ These geographies remained unchallenged as the field further expanded and matured (Bastos, "Parts of Asia;” Carvalho and Pina-Cabral; Castelo; Castelo, Thomaz, and Nascimento, et al.; Domingos; Jerónimo; Matos; Mata; Monteiro; Ribeiro and Ferreira;

\footnotetext{
${ }^{1}$ For a more detailed discussion, see Bastos “Luso-Tropicalism Debunked, Again," as well as the entire volume by Anderson et al. Lusotropicalism and its Discontents, among many others.

${ }^{2}$ Bela Feldman Bianco started this initiative at CEMI-UNICAMP, and it gained strength and substance through a week-long seminar, Tensões Coloniais e Reconfigurações Pos-Coloniais: Diálogos Críticos Luso-Brasileiros, held in Arrábida in Nov.1999 (Bastos, Vale de Almeida, and Feldman-Bianco). An earlier attempt to bridge social science research in different Portuguesespeaking sites took shape in Coimbra in 1990, with the support of Centro de Estudos Sociais and its mentor, Boaventura Sousa Santos, as the Congresso Luso-Afro-Brasileiro de Ciências Sociais, an event that was followed by bi-annual meetings in different Portuguese, Brazilian, Mozambican, and Angolan universities. The movement subsequently grew into a scientific society with its own journal, Travessias.
} 
Roque; Sanches; Santos; Xavier; among many others). We should now be ready to move beyond that frame.

\section{The Ways of a De-Imperial Turn}

A de-imperial turn has the potential to impact the field of Lusophone studies in several ways. First, it would re-settle the axis of Lusophone studies away from the traditional geographies of empire and into a more inclusive perspective on the multiple experiences of Portugueseness. That study would account for the unbound forms of mobility that stretch across different lands, oceans, and political spheres that are typically excluded from the grand narrative of conquest and expansion that dominates mainstream Lusophone historiography.

The field is already in re-alignment, as evidenced by recent publications. Eric Mourier-Genout and Michel Cahen's Imperial Migrations (2012) presents a collection of case studies that bend the boundaries of the two traditionally separated fields of empire and migration. Malyn Newitt's Emigration and the Sea (2015) documents how migration-related ocean crossings offer an alternative to the crusade and conquest narratives of Portuguese oceanic expansion. Darlene Sadler's Portuguese Speaking Diaspora (2016) brings in multiple perspectives on diasporic movements and reads empire through the cultural production of its participants, both European and non-European. António Hespanha’s Filhos da terra (2019) analyzes the fluid use of a mobile "Portuguese" identity at the fringes of the imperial connections in Asia, Africa, and elsewhere, echoing the ethnographic findings for South Asia presented by Margaret Sarkissian, Brian O'Neill, and others.

A second potential achievement of a de-imperial turn would be to deessentialize depictions of Portuguese culture/heritage as a timeless entity behind a variety of different social and political formations. In the long run, it may become desirable to reach a more dynamic approach, along the lines proposed by Hespanha, who discusses how the category of "Portuguese" fluctuates through geographies, chronologies, politics, commerce, and other social and cultural arrangements at the margins of empire. The point is not to throw out the "Portuguese" baby with the water of essentialisms such as "Portuguese character," or "Portuguese nature," or an immutable, homogeneous "Portuguese culture;" rather, the goal is to read the subject beyond the imagery produced by 
the politics of empire and analyze the intersections of such imagery with practices of exclusion, vulnerabilities, exile, disenfranchisement, social achievement, and other possible negotiations of social identities.

The de-imperial turn would also contribute to the understanding of how those with factual or fictional connections to Portuguese culture and history experience multiple identifications. This perspective should allow for a meaningful articulation with the work of scholars and narrators of diasporic experiences (e.g., Almeida, $O$ peso do hífen and The Tenth Island), post-colonial lives (e.g., Kilomba), strategic Portuguese identifications (Hespanha), and new angles on Portuguese Studies (Owen and Williams).

Last but not least, the shift would allow for more permanent connections between Lusophone studies and ongoing research on the internal diversities and racialized inequalities within Portuguese-speaking societies, in which the daily practices of racism and exclusion co-exist with discourses and ideologies of Lusotropicalist blandness and color-blindness.

\section{De-Imperializing Lusophone Studies: A Research Agenda Outside the Empire}

My own contribution focuses on the labor-related trajectories of Portuguese subjects, predominantly from the Azores and Madeira, into foreign imperial economies. This includes Madeirans in colonial British Guiana and Caribbean plantations from 1834 onwards and the social and geographical trajectories of their descendants. I also explore the trajectories, lives, and further trajectories of Azoreans and Madeirans in the plantations of Hawaii from 1878 (Bastos, "Portuguese in the Cane," "Açúcar, ananases," "Plantation Memories"); the demographically small but symbolically important settlement of Madeirans in Southern Angola in 1884-5 ("Migrants, Settlers and Colonists," "Maria India”); and the predominately Azorean communities that labored in the New England mills from the late nineteenth century ("Migrants, Inequalities”). More than just collating those separate streams to enhance their visibility for a wider audience, I aim to promote the cross-analysis of loosely connected cases in order to develop new analytical tools that might help sort the social categories generated in the process, the communities thus formed, the dynamic production of Portuguese identifications, and their intersections with representations of empire. 
In this section, I present in more detail the case of the Portuguese in Guyana, a group practically invisible in Portuguese Studies and among Portuguese historians - except in Madeira, where Demerara is a common reference (not as a variety of sugar but as a historical destination of migrant islanders). Throughout the nineteenth century, tens of thousands of Madeirans went to Demerara, as well as Essequibo and Berbice, the other sections of British Guiana. They went first as sugar plantation laborers, and they later expanded into a flourishing community mostly supported by commerce (Spranger).

Why did Madeirans go to the British Guiana plantations in the first place, when did they go, how many went there, and how many stayed? The first, most intense and dramatic cycle of migration from Madeira to Demerara occurred between the mid-1830s and the late 1850s, exactly between the end of slavery in the British Empire and the systematic recruitment of indentured South Asians for the Caribbean. Until Emancipation, in 1833-34, sugar plantation labor had been supplied by enslaved Africans. Apprenticeship, a social experiment meant to grant the transition by which formerly enslaved persons were supposed to perform the same plantation tasks while on a different legal status, failed on most fronts. Planters turned to other sources of labor: Africans rescued from slave ships run by rivals, the free Krou from West Africa, and Madeiran islanders.

Madeirans left their island sometimes to escape famine and violence, sometimes in the belief that they would find wealth, sometimes not knowing where they were going at all. The conditions of their recruitment were often obscure. There are currently no direct testimonies, no diaries, nor complete travel logs that might provide a first-hand account of the experience of crossing and of arrival; however, there are other sources that do permit a closer understanding of the Madeirans' experience, their numbers, locations, roles in the plantations, gender distribution, state of health, and patterns of morbidity and mortality (Bonyum). The journey to Guiana was a daunting adventure; it involved boarding a ship (often illegally), crossing the Atlantic, arriving safely in Guiana (often enough celebrated by passengers with singing and dancing right on the docks), and ending up on a plantation with random levels of violence.

The first documented arrival of Madeirans in Guiana reports that forty islanders disembarked from the Louisa Baillie on 3 May 1835 and went to the plantations of La Penitence, Liliendaal, and Thomas (Menezes 5). After that, many more left Madeira for the British colony. Once there, many died of fever 
or due to brutal work conditions. Others survived and even thrived in a place where the production of difference- expressed by culture and "race" and defined by one's position in the labor market - was at the core of all social dynamics (Williams). In effect, the local Portuguese became a "race," distinct from other groups. They were not "white" like the plantation-owning class of British and Dutch ancestry, nor were they "Black" like the descendants of Africans displaced by enslavement. They were not "Indian" like the descendants of displaced South Asian indentured laborers that came later, nor were they "Amerindians" like the indigenous groups that had been there before anyone else. They were also distinct from other groups, such as the Chinese, who, like the Portuguese, had settled in Guyana for work and business. ${ }^{3}$

In the late 1850s, when South Asians became the main suppliers of labor for British Guiana plantations, the local Portuguese were less likely to be found in the sugar fields. Many did well in commerce, from as early as 1843 (Menezes 31). They were famous for their rum shops, but they also sold dry goods and worked the streets as hucksters/street vendors. This niche was partly taken from the emancipated Africans and their descendants, who sought alternatives to plantation work. In a society as deeply racialized as colonial Guiana, the Portuguese were extended credit and other means to support their activity, while the Afro-Guianese, or Creoles, were often excluded. The tensions between the two groups exploded in 1856, in the so-called Portuguese Riots, which were fueled mostly by the anti-Portuguese preaching of Pastor James Orr, who presented himself as the archangel Gabriel. The riots targeted Portuguese property and goods but not the people (Mello).

Although not all of the Portuguese in the colony achieved commercial success, the ones who did so helped to shape a narrative of upward mobility and prestige. In the second half of the nineteenth century, those who moved from Madeira to Georgetown and its vicinities were no longer primarily headed to plantations; rather, they were trying to become a part of the successful Portuguese

\footnotetext{
${ }^{3}$ While the notion of "six races" or "six groups" remains stable throughout the later history of colonial Guiana and independent Guyana, categories have varied with time. In the past, the category "mixed" was the sixth, to be later erased and replaced by that of "Chinese" - which are also an important demographic group with trajectories not unlike the Portuguese. Recently, "mixed" came back, leaving out "whites," who are now demographically almost insignificant. "Portuguese" remain a distinct group today as in the past, although their demographic expression has diminished drastically, since many have moved to Canada or the UK.
} 
business community. They now ranked above the laborers in economic power and social status but below the white plantation owners, who were a numerical minority of people of British and occasionally Dutch descent. The Portuguese in Guiana were not "white” like the planters and rulers-they were something else, and they fit into another racial box in the local classification. In any case, they were Roman Catholic, not Protestant like most planters. The Portuguese would remain a separate category-one of the races or nations or peoples that composed the complex tissue of colonial British Guiana and the equally complex tissue of the modern Republic of Guyana. ${ }^{4}$

As for the total number of Madeirans who moved to British Guiana, one can make a rough estimate of magnitude and degree by using a combination of sources. Portuguese-Guyanese historian Mary Noel Menezes reports that 30,645 Portuguese arrived in Guiana during the period of state-sponsored migration from 1841 to 1882 (5). It is also certain that many others travelled there unsponsored and without official documents (Spranger). Primary sources provide some leads regarding their impact and importance; they also allow one to outline a periodization and typology of migration from Madeira to Guiana.

In 1850, the Governor of Madeira, José Silvestre Ribeiro, shared with the central government his anxieties about the outflow and quasi-slave conditions endured by Madeiran migrants in British Guiana. He believed at the time that 30,000 to 40,000 had already left Madeira for Demerara (José Silvestre Ribeiro). In 1851, the Portuguese consul in Georgetown mentioned 18,000 Portuguese in British Guiana, 14,000 of which worked directly in sugar and without whom production would collapse (Haynes). An unknown number of them would have succumbed to the dreadful conditions of life on the sugar plantations and the harshness of the environment. In Lisbon, some politicians referred to the situation as a collective embarrassment and pleaded to have them settle in Portuguese colonies instead (Arquivo Histórico Ultramarino "Sobre o estado" and "Emigração").

Nearby Suriname, formerly colonial Dutch Guiana, also occasionally imported Portuguese laborers (Brand Flu). Suriname's social mosaic is nonetheless historically different from that of Guyana, particularly with respect

\footnotetext{
${ }^{4}$ In accordance with local use, “Guyana” refers to the independent nation, while "Guiana” refers to the colony.
} 
to the "Portuguese." In Dutch Guiana, there were seventeenth- and eighteenthcentury early settlers and plantation owners of Iberian Sephardic Jewish ancestry who were known as "The Portuguese Nation," or just “The Nation.” They mostly came from Recife or Amsterdam, they built the first synagogue in the colony, and they established an agricultural community called the Jodensavanne (Jerusalem by the River). It became a powerful sugar center deep in the jungle. ${ }^{5}$ The project collapsed later in the eighteenth century, due to a number of difficulties, including the attacks from Maroon communities formed by those who had run away from enslavement. The community ultimately moved to Paramaribo, where they built another synagogue that replicated the Portuguese synagogue in Amsterdam and its Caribbean and New York counterparts (see, among others, Arbell; Davis; Ezratty).

The neighboring Caribbean islands of Trinidad and Tobago, Curaçao, St. Vincent, St. Kitts and Nevis, etc., also experienced waves of Portuguese arrivals at different moments and in different social, economic, and political contexts. These ranged from the resettlement of Sephardic Jews from Recife to Curaçao in the eighteenth century (Ezratty) and the arrival in the nineteenth century of Protestant exiles in Trinidad (Ferreira) to the high-risk recruitment of Madeiran men to work the oil platforms of St. Vincent during World War Two (Drummond et al.) - a route that opened the way for intense migration to the neighboring country of Venezuela.

The analysis of those trajectories and their demographic expression has the potential to place into question certain assumptions about the Portuguese empire, particularly its vitality between cycles and the longevity of the administration of African territories. Towards the end of the nineteenth century, the number of Portuguese-born men and women living in the territories of the Portuguese empire was much smaller than that of those who lived in other empires and nations. Portuguese men and women moved away from Portugal, but not to its colonies. They went first and foremost to independent Brazil, where approximately 1.7 million arrived between 1837 and 1968, a million of whom reached Brazil in the forty years between 1890-1930 alone (Gladys Sabina Ribeiro 176-77). They went later to Argentina (Borges), to South Africa (Gupta),

5 The author would like to thank Harold Sijlbing for a guided visit to Jodensavanne in 2018, part of the conference "Slavery, Indentured Labour, Migration, Diaspora and Identity Formation" at the University of Suriname. 
and other destinations. Around 1900, tens of thousands of Portuguese subjects lived in British Guiana, and a few more thousands lived in Hawaii and New England.

In contrast, there were at the turn of the twentieth century only a few thousand Portuguese-born residents and descendants of Portuguese-born residents in Angola, and there were fewer than a thousand in Mozambique, to mention only the two largest territories claimed by the Portuguese empire. ${ }^{6}$ The Madeiran settlement in the Huíla Plateau of Southern Angola consisted of only a few hundred people (Medeiros; Bastos, "Migrants, Settlers"). The massive, sponsored colonization of Angola and Mozambique only took place in the second half of the twentieth century (Castelo, Passagens). In the meantime, the African population remained categorized as "indigenous," which enabled de facto forced labor (Jerónimo; Monteiro). Some Africans were later able to become Portuguese citizens (assimilados) by adopting "civilized" mores. While the notion of assimilados became currency in the Portuguese propaganda as a token of their humanitarian tolerance regarding color lines vis-à-vis British racialist rigidity, the number of assimilados was never expressive.

In sum, rather than feeding a supposedly long-lasting Portuguese empire, Portuguese settlers moved away from it in large numbers and found home elsewhere, often in competing empires, cutting sugar cane in faraway plantations or providing the labor force for the cotton mills of New England.

\section{Paradoxical Intersections of Empire and Diaspora}

During an exploratory trip to Guyana in 2011, I learned that most local Portuguese had moved out of the country in the 1960s, either during the years that led to independence or in its aftermath. I also learned that they had mostly moved to Scarborough, a neighborhood in Toronto where many residents are of Guyanese and Caribbean descent. I was not able to reach Toronto before 2018,

\footnotetext{
${ }^{6}$ In 1844, the estimated number of European inhabitants in Angola was 1,832 out of a total of 386,163 (Lima). In 1899, there were 11,491 Europeans out of a total population of 966,501, of which 853,972 were classified as Africans and 101,038 were non-specified ("Mappa da População”). For the entire area of Mozambique in 1900, there were 953 Portuguese out of a total of 107,677 inhabitants (Sousa 453). For more, see Counting Colonial Populations.
} 
but I did eventually find a few members of that elusive group in Scarborough and other parts of urban and suburban Toronto. ${ }^{7}$

Knowing that the city had been a prime destination for Portuguese migrants since the late 1950s, when Ontario opened to international immigration, I wondered if there were any connections between the two groups. Literature on the Portuguese in Toronto made no reference to Guyana. No wonder, I learned later, because while the small group of Portuguese-Guyanese in Toronto knew about the local Portuguese (the latter are quite visible, owning shops, restaurants, bakeries and other businesses), the reverse did not occur. Our queries were met with genuine surprise, to the point that the local press and radio stations asked us for interviews to share publicly this hidden aspect of the Portuguese diaspora (Araújo, “The Arrival,” "Madeira, Guiana”). One of those interviews occupied an entire slot on the popular radio station Radio Camões. It was there that I experienced one of those situations where empire and diaspora intersect in ways that propel further analysis.

Toronto's Radio Camões has its headquarters in the Mod Club building at Camões Square, by College Street, near a number of Portuguese-owned businesses. The building stands out for its imposing façade. One of its walls and a section of the pavement are decorated with images and symbols of Portugal: flags, traditional cobblestones, etc. There is also a Portuguese Hall of Fame with pictures of successful Canadians of Portuguese descent. Many of the symbols evoking Portuguese imperial history-ocean trade, caravels, Henry the navigator, quotes from Camões's The Lusiads, etc.-may look familiar to those acquainted with other Portuguese cultural centers in other parts of the world. In the sound room inside the Mod Club building, however, there was something else: a row of the national flags of CPLP's member countries. It was not the empire proper that was being celebrated but rather its aftermath, the geography that prolonged it, the sum of different nationalities that underwent different

\footnotetext{
${ }^{7}$ I conducted my research in Toronto with the collaboration of João Sardinha, a guest researcher on The Colour of Labour project. Thanks to Dr Alissa Trotz for her suggestions and for sharing her connections with the alumnae associations of Guyana's high schools. Thanks too to the many generous Canadian-Guyanese of Portuguese descent who consented to being interviewed, and Irene Marques for sharing her connections in the community. Although not everyone interviewed mentioned the politics of Peter D'Aguiar in pre-independence days, many did, and analysts suggest that the polarization and alliances promoted by his party brought difficulties to the Portuguese group as a whole (Drayton; Bisram).
} 
historical paths and politics, an essentialized Portugal-at-large projected through a materialization of Lusofonia.

It felt like walking into a three-dimensional paradox. In one of the epicenters of the Portuguese-speaking diaspora in North America, in a well-endowed and neatly run cultural center supported by the community, we found ourselves in a room full of flags of distant countries, rather than of Toronto or other North American sites with influential Portuguese communities, like Montreal, British Columbia, New England, New Jersey, or California. But for those familiar with that room, there was no contradiction: it was a way of celebrating heritage via a meaningful, wider belonging that echoed in contemporary terms the older tradition of using the symbols of empire in contexts of exile from the empire.

\section{Further Intersections: From Community Celebration to Hyperbolic Nation}

Toronto is not alone in adopting symbols of empire and post-empire as a means of displaying Portuguese identity and heritage in labor-based diaspora communities. Iconic symbols of overseas exploration and conquest, such as caravels, navigational instruments and charts, and replicas of the stone pillars with sculpted coats of arms that navigators left on distant shores to mark their presence and claim priority and territorial rights (the padrão), can be found in many places of the Portuguese diaspora in the US - on the East Coast, in Northern and Southern California, in downtown Honolulu—as much as in the actual post-empire enclaves of Goa or Macau.

Some of the North American monuments are particularly expressive, as is the case at the Bretton Point site in Newport, Rhode Island. This is perhaps the most spectacular of its kind, as it reproduces, in a vast area where the land ends, the atmosphere of the Portuguese southwestern cape of São Vicente, the mythical

site of the "School of Sagres," an entity that stands for the dynamics of knowledge and development of navigational skills and tools that were a precondition for the transoceanic European voyages of the fifteenth century onward. There visitors can read that the Portuguese "gave new worlds to the world" as they stand in one of the very places "given" to the world (according to the equation) by those across the ocean. 


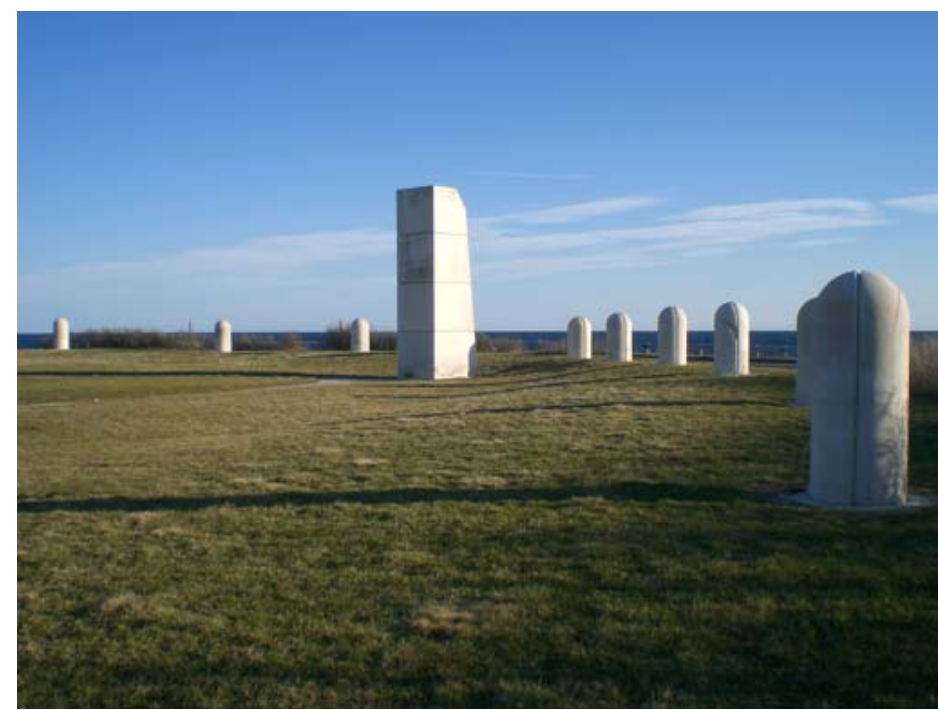

Image 1. Bretton Point, Newport, Rhode Island. Photo by author.

Despite decades of critical debates on the meaning of the encounters between European settlers and Native American peoples, the Eurocentric idiom of discoveries was used to celebrate the heritage of some-precisely a minority group that descended from labor migrants. That choice of words was meant to provide evidence of a past of grandeur, connecting it to a present in need of acknowledgement—-the demographically expressive yet "invisible” Portuguese community in North America (Smith; Baganha; Feldman-Bianco; Holton and Klimt; Papp). To challenge depictions that they considered demeaning, the New Bedford Portuguese community also employed the theme of discoveries and Portugal's pioneering historical grandeur (as expressed in the epic of Camões) at a rally they organized in 1924 (Taft; Bastos, “Migrants” 174-76).

\section{A Rock in the River Tauton}

In contrast with the creators of monuments like the one in Newport and others found across the world, who follow an accepted pattern of celebrating Portuguese discoveries, there were other imaginative cultural entrepreneurs in the diaspora communities who attempted to promote Portuguese grandeur through symbols beyond that standard imagery. I will illustrate with two cases of hyperbolic 
identity boosting in two different locations in the US-Southern New England and New York City.

The first and perhaps most picturesque of those cases is the Dighton Rock, the subject of nationalist interpretations and appropriations (Almeida; Fernandes; Hunter). European settlers first came across the forty-ton boulder in the late seventeenth century on the banks of the Tauton River where it runs between the towns of Dighton and Berkley (Massachusetts). It measures roughly 5 x 9.5 x 11 feet and is richly inscribed with petroglyphs. There are multiple layers of marks, some of them putatively anthropomorphic, some putatively alphabetic. Their date and origins are unknown; they could have been carved by Native Americans, by visiting Vikings, or by more recent dwellers.

The petroglyphs were known in wider circles of explorers and archeologists, but there was no consensus on how to interpret them. In his 1835-39 Royal Geographic Society of London expeditions to the interior of Guiana, Robert Schomburgk commented that the petroglyphs found on the Comuti, or Taquary rock, to which he referred as an unsolved mystery, had "a resemblance to the sculptures found to the eastward of Ekaterinburg, in Siberia [...] and at Dighton, near the banks of the Taunton river" (4). In the 1910s, a Brown University professor named Delabarre interpreted one of the inscriptions as "1511." As a psychologist engaged in cognitive theories, he claimed that once " 1511 " was seen, it could no more be "unseen.” It was taken as an indicator of a date. Not just any date: a date of arrival. Perhaps the arrival of some Portuguese discoverers, maybe the lost travelers Miguel and Gaspar Corte Real, the navigators who left Portugal in 1501 and in 1502 and never returned. The speculative connection was turned into a fact. From then on, everything else in the inscriptions was interpreted as signs of early Portuguese presence in what is now New England. Delabarre could also read in the inscriptions the name of Miguel Corte Real and what could be a section of a coat of arms. Later, José Fragoso, a lecturer in Portuguese at New York University, claimed to have identified the cross of Christ and the quinas, symbols used in the sixteenthcentury Portuguese caravels. From then on, the Dighton Rock became highly prized as a symbol of Portuguese culture. Portuguese-born, New England resident Luciano da Silva became its main promoter, to the point that he suggested a revision of history to credit the Portuguese for the discovery of North America (Almeida, O peso 108). 


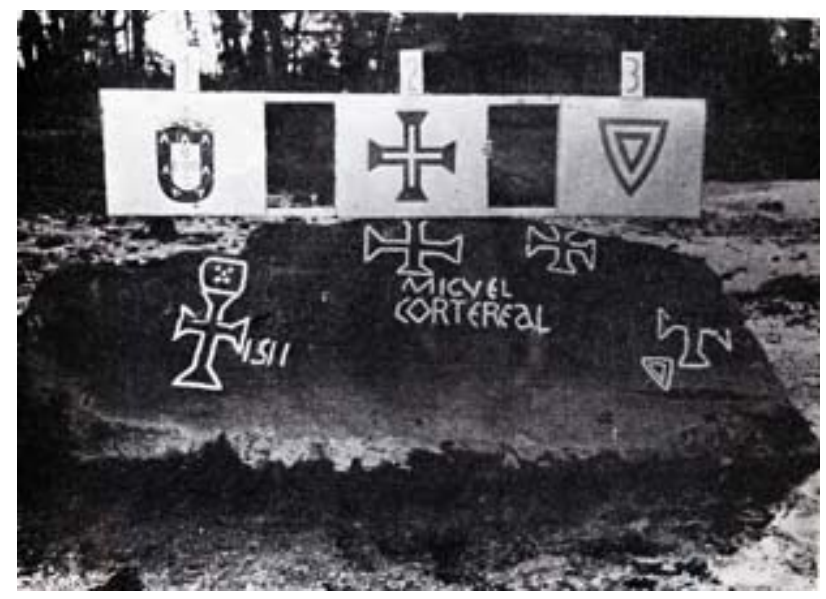

Image 2. Dighton Rock, reproduced from M Luciano da Silva, Os pioneiros portugueses.

For interpreters such as Silva, the Dighton Rock provided written-in-stone evidence of the historical value of the Portuguese. It was officially musealized in a Massachusetts park with a solemn celebration involving the local Portuguese authorities. Historian Gilberto Fernandes would refer to this as an act of "filiopietism," or exaggerated praise of ancestors, in his own analysis of the disputes over the Dighton Stone and California’s Cabrillo Monument.

As Douglas Hunter has argued, there is good evidence that the inscriptions on the Dighton Stone were put there by indigenous Americans, and that attempts to link them to the Portuguese, the Vikings, or even the Phoenicians are part of a general trend that seeks to erase America's indigenous past from collective memory. For the Portuguese in New England, however, the Dighton Rock has become a valuable asset in the community's struggle for visibility by means of an "organic" link to navigational feats from the past: an early arrival previously unacknowledged but now visible for everyone to see. Also significant is the fact that this discovery takes place precisely where this heroic history intersects with the realities of the diasporic communities of Portuguese working men and women who contributed to the economy, achieved some economic success, and yet remained mostly invisible and unacknowledged in the public sphere. 


\section{A Queen in Queens, NY}

Another expressive attempt to promote Portuguese visibility in the US involves efforts to celebrate Queen Catherine in the New York borough of Queens. Catherine of Bragança was a Portuguese princess who married King Charles II of England in 1662, an alliance achieved after political negotiations against England's and Portugal's common rival, Spain. Among other valuable assets, Catherine's dowry included the island of Bombay (now Mumbai) in India. There are claims that she also brought to England the habit of tea drinking, the taste for orange marmalade, and the use of the fork - a tale often brought up by people of Portuguese ancestry when scorned by the English. ${ }^{8}$

The alleged link between Catherine and Queens dates back to the time when the British replaced the Dutch in the city. The English Duke of York renamed New Amsterdam after himself, and the boroughs after those close to him: Kingsborough (Brooklyn) after his brother the king, Queensborough after the queen, and Richmond County (Staten Island) after the Duke of Richmond. That there was a real queen behind the name of the borough of Queens, one that was English by marriage and Portuguese by birth, was news to most New Yorkers. The movement to make that link visible started in the 1980s, owing much to the initiative of a young Portuguese-born resident of New York, Manuel Andrade e Sousa. The "Friends of Queen Catherine" initiative was officially launched in 1990, and it brought together a cosmopolitan lot that included celebrities and organizations from the US and Portugal. The ambitious plan included the entire renovation of the run-down area of Hunters Point, across the East River from midtown Manhattan, to accommodate a grandiose, 35-foot-tall statue of Catherine. The mayor of Queens, Claire Shulman, previously unaware of a link between the borough's name and a historical queen, endorsed the project after getting acquainted with it and exposed to Portuguese history and culture (Brozan). In 1992, after a public competition, renowned feminist sculptor Audrey Flack was commissioned to create the statue (Fried).

\footnotetext{
${ }^{8}$ Even Elvira Osorio Roll, one of the few literary writers who depicts the Portuguese community in the plantations of Hawaii and the stigma they experienced vis-à-vis the ruling Anglodescendants, uses these references as identity boosters in her novel Hawaii's Kohala Breezes (see Bastos, "Portuguese in the Cane").
} 
Everything seemed to be rolling, except for one disregarded yet crucial detail. Unlike for the Newport monument and the Dighton Rock inauguration, which were supported by the strength and desire for public acknowledgement of the Portuguese communities of Rhode Island and Massachusetts respectively, the Queen Catherine project was not grounded in any local community. There were hardly any Portuguese in Queens at that time. There had been an important community in downtown Manhattan in the early twentieth century, but by the 1980s it had been reduced to a few residents and shop owners on Thompson and Sullivan streets; by then, most Portuguese families had moved into the residential suburbs of Long Island and New Jersey. There were also important Portuguese communities in nearby Newark and Elizabeth, New Jersey; however (and despite its undeniable multiculturalism and immense variety), this was not the case in Queens. Instead, there were groups that challenged a project honoring a figure with a past potentially tainted by involvement in the transatlantic slave trade.

The most expressive criticism came from Queens's African American residents, who associated Catherine not with a group of hardworking migrants in search of recognition but with a British monarch who had benefited directly from the slave trade (Bearak). Other criticisms piled up. The Irish did not want to celebrate an English monarch, while skeptics challenged the loose evidence linking Catherine with Queens. Protests erupted in 1997, and Mayor Shulman was put in a difficult position. In the end, she chose her constituency over the project, much to the dismay of the "Friends of Queen Catherine," who had been able to raise almost two million dollars from private funding over the years (Weir). This was also unwelcome news to Audrey Flack, whose research on Catherine had unveiled, in her own words, "a good human being," not the evil slavery profiteer portrayed by anti-statue activists, and someone who "had dark Portuguese skin and was made fun of for that” (Kilgannon). Interestingly enough, Flack had developed a representation of Catherine as a mixed-race figure. Flack's Catherine was not to be seen by New Yorkers, however, and the bronze for the statue was melted in a foundry. 


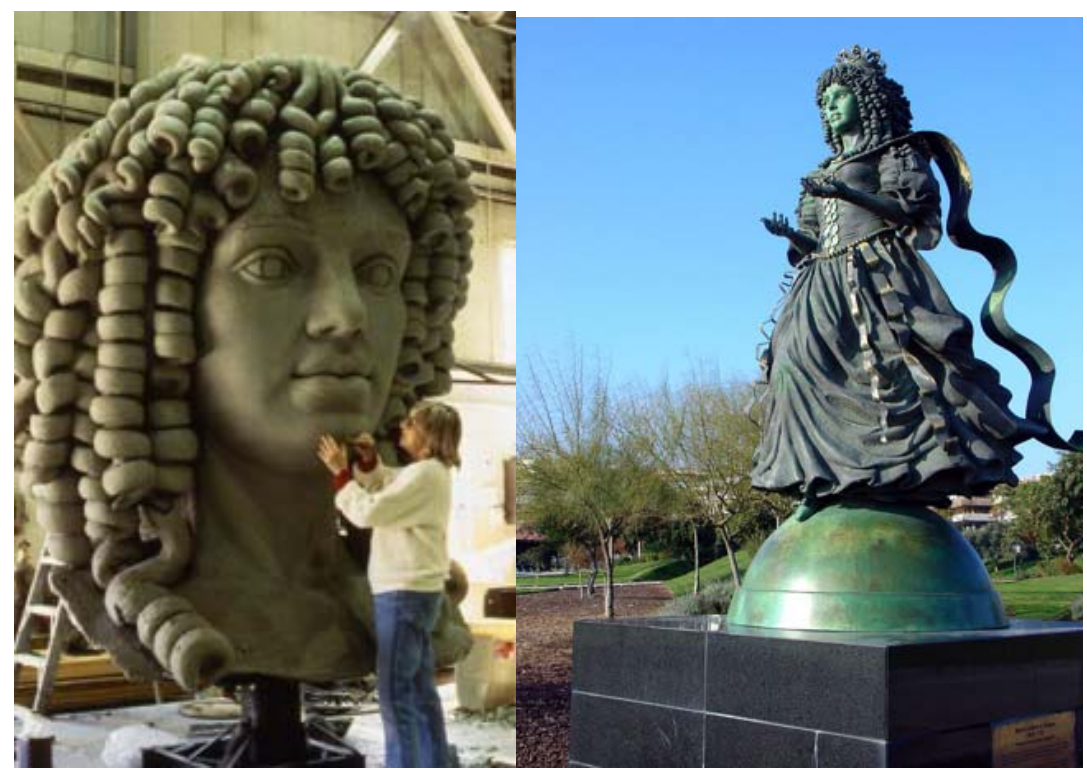

Image 3. Left: Artist Audrey Flack working on the statue of Catherine (originally published in the New York Times); Right: Quarter-sized replica of the statue at Parque das Nações, Lisbon. Source: Audrey Flack's website, with the kind permission of the artist.

The end of the New York project was not the end of the story. While the original statue was melted, a quarter-size replica made its way into public view in Lisbon's Parque das Nações. This was the former site of EXPO98, an event in which the national narrative was reconfigured away from the traditional imperial tropes toward a more contemporary language of connecting different worlds through the ocean. There, Catherine found an uncontested home that looks into a multicultural future rather than standing for a contested past.

\section{Intersections of Labor and Experience}

There are counterpoints to the celebration of an exaggerated and imperialist version of Portuguese history and culture in other parts of the world. This is the case of Hawaii, where Portuguese men and women also labored in exile. Caravels and coats of arms make occasional appearances there too, and some of the local Portuguese poetry evokes the epic themes of Camões's The Lusiads, most celebrations of ancestral pride intersect with the shared experience of the 
displaced groups who came to Hawaii as labor for the sugar plantations. As with other groups, the favored symbols revolve around ancestral culture. Some have been directly imported, like Roman Catholicism and Holy Ghost festivals, or simply refashioned, like ritual and secular foods, including the massa (sweetbread), sopas (Holy Ghost food), malasadas (fried dough), vinha d'alhos (garlic-and-vinegar pork), pastel-de-nata (custard pie), music, dances, and the ubiquitous Galo de Barcelos. In Hawaii, there is no erasure of the factual history of labor: celebrating labor in the harshness of the plantations is a guide to history and collective identities, even though these are far from settled, and new tensions and dynamics between groups continue to evolve (Bastos, "Plantation").

In California, the celebration of Portuguese heritage also combines the occasional use of old imperial symbols with a serious attempt to retrace the history of local Portuguese laborers. An eloquent example can be found in the Portuguese Historical Museum in San José (one of the main attractions of the city's Kelley Park). ${ }^{9}$ The museum accounts for the usual themes of Portuguese ethnic pride, as well as traditionally Azorean symbols evoking the Holy Ghost. The building replicates the first permanent império in San José (1915), and some of its sections showcase the feasts that are of the highest importance to California's Azorean community (Leal). Above all, the museum reflects the histories of arrival, struggle, labor, and achievements of the Portuguese who came to California. Interestingly enough, there is a section of the museum that acknowledges the Portuguese of Hawaii who eventually also came to California. Unlike Toronto, where the local Portuguese did not know of the PortugueseGuyanese diaspora, the Portuguese in California acknowledge and embrace the Portuguese of Hawaii who moved there. The only difficulty between them emerges from the use of spoken Portuguese-lost to English in Hawaii but quite alive among the Portuguese in California.

\section{Reconfigured Intersections, Present and Future}

What can those in the field of Portuguese Studies learn from the intersections, tensions, assemblages, and paradoxes described in the present paper? In what

\footnotetext{
${ }^{9}$ Thanks to Antonino Pascoal, Anita Pascoal, and Veronica Sousa for generously sharing their knowledge and guiding me through a special visit to the museum in 2018.
} 
ways does their study help to de-imperialize the field? I suggest that they expand our interpretive lenses and allow us to understand past, present, and future complexities and struggles. This is best exemplified by current events in Lisbon, Portugal's capital and the center of its late empire.

Culture wars over meaning, identity, and iconographies of empire emerged in Lisbon later than in other places, but they have emerged nonetheless (Barreiros, et al.). As late as 2018, the mayor of Lisbon endorsed a project to create a Museum of Discoveries to celebrate national history and generate tourist revenue, and he was met with severe criticism. While many Portuguese likely supported the project, many others contested it on political and historical grounds, with letters gathering hundreds of signatures from academics, artists, and activists (Margato; Nóvoa). At the same time, voters on the city's orçamento participativo had approved the development of a Memorial to the Victims of Slavery. The proposal had come from DJASS-Associação de Afrodescendentes, one of an increasing number of Afro-Portuguese groups focused on cultural and political matters. Several artists of African descent were invited to present projects to be located in the Campo das Cebolas, a former pier in downtown Lisbon where much of the trade in enslaved persons took place in the past. The public voted on the three finalists' projects — one by Lisbon-born Grada Kilomba, another by São Paulo-born Jaime Laureano, and the third by Luanda-born Kiluanji Kia Henda. The winner was Henda's high impact "Plantation: Prosperity and Nightmare," imagined as a large-scale sugar plantation with 540 three-meter high, black aluminum "sugarcanes" spaced 1.5 meters apart. In all, the installation creates an impressive atmosphere of growth and oppression (Lobo; Salema).

This installation brings the nexus of sugar-empire-enslavement-racism full circle, and it carries several layers of meaning. Lisbon is now ready to face the physicality of the sugar cane fields, where a prized commodity was produced and fortunes amassed at the cost of a bloody trade in human beings. Sugar fueled the economy of empire in the Atlantic, the trade in Africans to Brazil and the Caribbean, and, as I have mentioned earlier in the present essay, the emigration of many Portuguese islanders to foreign plantations. The visualization of a sugarcane field may well prompt a deeper reflection on the legacies of violence and racism, an acknowledgement of the deeply historic roots of contemporary social inequalities, and a guide to possible acts of mitigation and reparation. 


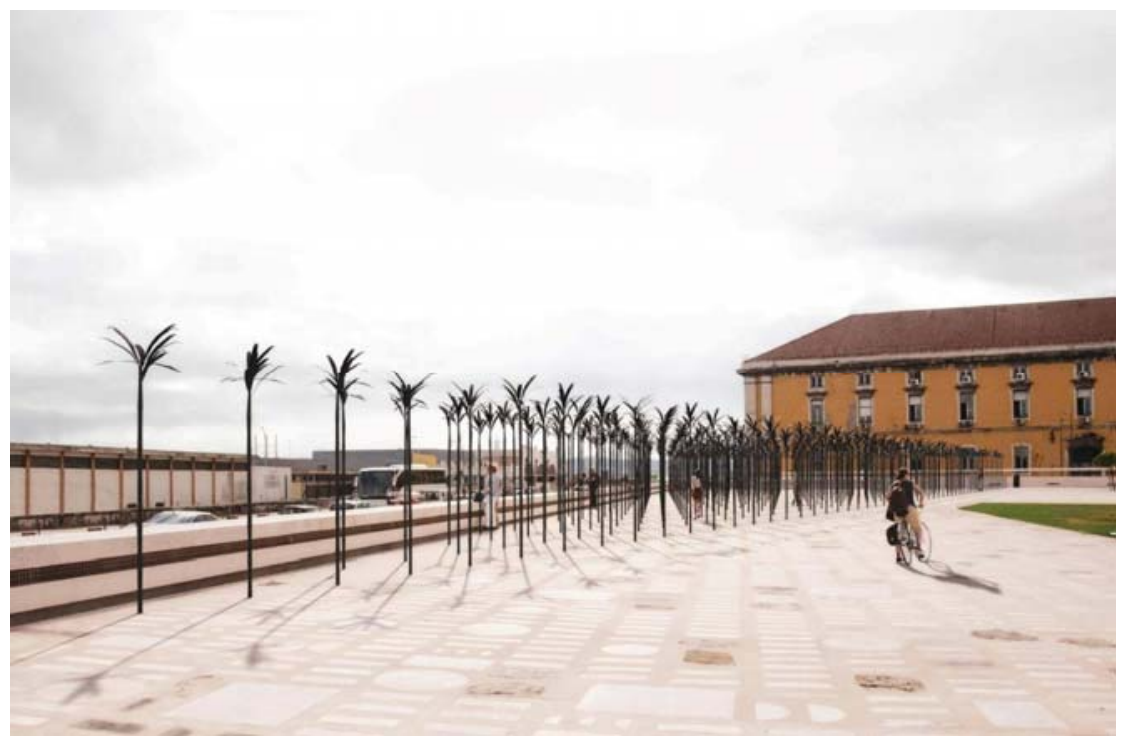

Image 4. Kiluanki Kia Henda’s “Plantation: Prosperity and Nightmare” project for the Lisbon memorial to enslaved people.

To conclude, it is useful to provide a note on the coexistence of meanings and social landscapes. When giving way to new arrangements, the older ones do not fully disappear from the scene. While new, critical forms of addressing the past complicate the perception of history, icons of empire (and Portugal's fascist past) such as the Padrão dos Descobrimentos in Belém and the imperial map etched into the adjacent pavement remain tourist attractions and sources of pride for many people in Portugal and the Portuguese diaspora. However, these sites now compete with alternative tours of African Lisbon, such as Naky Gaglo's African Lisbon Tour, which invites visitors and Lisboetas alike to "open the debate and break the taboo" about prevailing assumptions on the African slave trade and colonialism (African Lisbon Tour).

When complete, Lisbon's memorial to enslaved persons will stand out in the urban landscape in inescapable ways. A new perspective on empire and its implications will emerge in the public sphere and intersect with the persistent attachment to symbols of empire. One hopes that it will do so in ways that may allow for further reflection on collective identities through the paradoxes of 
history, politics, and the dense, rich, complex, and multilayered cultural production of Portuguese culture and identity around the globe.

\section{Acknowledgements}

This article has been in the making for some time. I conceived part of it (connecting Bretton Point, the Dighton Rock and the Queen Catherine project) while working as a visiting professor at Brown University (2006-07) under the supervision of Onesimo Teotónio de Almeida, to whom I owe thanks for the many conversations and insights generously shared. In response to Maria Cardeira de Silva's challenge to address heritage and empire, I presented my analysis in a paper at the ninth SIEF Conference at the University of Ulster in 2008 ("Written in Stone”). I developed an expanded and more reflexive version in response to an invitation from Maria Paula Meneses and Boaventura Sousa Santos to give a plenary talk at the Portugal: Entre Desassossegos e Desafios conference at the Universidade de Coimbra in 2011 ("Pedra, corpo, palavra, água”). The current version was shaped in response to an invitation from Raquel Ribeiro to serve as a keynote speaker at the 2019 International Conference of the Association of British and Irish Lusitanists at the University of Edinburgh in 2019 ("Intersections of Empire”). I am thankful to those that invited me to speak and to their audiences for the discussions held. The current analysis includes results from The Colour of Labour-The Racialized Lives of Migrants project, funded by an Advanced Research Grant of the European Research Council (\#695573) that has generously allowed me to conduct field and archival research. I am thankful to the ERC and my home institution, ICS-ULisboa, for its support during this long journey, and I am indebted to a large number of people who helped me along the way. Special thanks go to Marcelo Moura Mello, Brackette Williams, Richard Drayton, and Virginia Domínguez for our exchanges on matters of Guyana; to Ana Isabel Spranger, Claudia Ferreira Faria, and Susana Caldeira on matters of Madeiran migration; and to Marta Macedo and Nicholas Miller, team members of The Colour of Labour, for comments on earlier versions

of this paper. Finally, my thanks to Vincent Barletta, Pedro Schacht, and two anonymous readers for their very useful suggestions. 


\section{Works Cited}

Alexandre, Valentim, and Jill Dias, editors. O império africano: 1825-1890. Estampa, 1998.

Almeida, Onésimo T. O peso do hífen. Imprensa de Ciências Sociais, 2010.

—. Tales from the Tenth Island. Seagull, 2006.

Anderson, Warwick, Ricardo Roque, and Ricardo Ventura Santos, editors. Lusotropicalism and its Discontents: The Making and Unmaking of Racial Exceptionalism. Berghahn, 2018.

Araújo, Humberta. "Madeira, Guiana Inglesa e Canadá: um estudo histórico pioneiro europeu.” Milénio: Galeria dos Pioneiros Portugueses, 19 Oct. 2018, www.mileniostadium.com/edicoes/edition-october-19-2018.

- . "The Arrival of the Portuguese (Madeira Island) in British Guiana.” Milénio: Galeria dos Pioneiros Portugueses, 18 Oct. 2018, pioneersgallery.ca/thearrival-of-the-portuguese-madeira-island-in-british-guiana.

Arbell, Mordehay. The Jewish Nation of the Caribbean: The Spanish-Portuguese Jewish Settlements in the Caribbean and the Guianas. Gefen, 2002.

Arquivo Histórico Ultramarino, Conselho Ultramarino. Índia, cx. 14, doc. 453, "Sobre o estado de miséria em que se acham os colonos portugueses em Demerara,” 9th May 1854- 15th April 1856

—, Reino, cx. 2, doc. 32, "Emigração de madeirenses e açoreanos para a Guiana Britânica (Demerara),” 1852.

Baganha, M. Ioannis. Portuguese Emigration to the United States, 1820-1930. Garland, 1990.

Barreiros, Inês Beleza, Patrícia Martins Marcos, Pedro Schacht Pereira, and Rui Gomes Coelho. “O padre António Vieira no país dos cordiais.” O Público, 2 Feb. 2020, publico.pt/2020/02/02/ sociedade/ensaio/padre-antonio-vieirapais-cordiais-eterna-leveza-anacronismo-guardiaes-consenso-lusotropical1902135.

Bastos, Cristiana. "Açúcar, Ananases e ilhéus portugueses no Hawaii: dinâmicas de migração, etnicidade e racialização no terreno e no arquivo.” Etnográfica, vol. 23. no 3, 2019, pp. 777-98.

-. "Intersections of Empire, Post-empire and Diaspora in Lusophone Studies." Plenary Talk at the 2019 International Conference of the Association of British and Irish Lusitanists, U of Edinburgh, 7 Sept. 2019. 
—. "Luso-Tropicalism Debunked, Again: Race, Racism, and Racialism in Three Portuguese-Speaking Societies.” Luso-Tropicalism and Its Discontents, edited by Warwick Anderson, Ricardo Roque, and Ricardo Ventura Santos, Berghahn, 2019, pp. 243-64.

—. "Maria Índia, ou a fronteira da colonização: trabalho migração e política no planalto sul de Angola.” Horizontes Antropológicos, vol. 15, no. 31, 2009, pp. 51-74.

- "Migrants, Inequalities and Social Research in the 1920s: The Story of Two Portuguese Communities in New England." History and Anthropology, vol. 29, no. 2, 2018, pp. 163-83.

-. "Migrants, Settlers and Colonists: The Biopolitics of Displaced Bodies." International Migration, vol. 46. no 5, 2008, pp. 27-54.

—. "Parts of Asia, Today: Beyond Lusotopic Nostalgia.” Portuguese Literary \& Cultural Studies vol. 17/18, 2010, pp. 13-24.

—. "Pedra, corpo, palavra, água: memórias deslocadas e narrativas fantásticas." Plenary Talk at Portugal: Entre Desassossegos e Desafios, Centro de Estudos Sociais, U de Coimbra, 17 Feb. 2011.

—. "Plantation Memories, Labor Identities, and the Celebration of Heritage: The Case of Hawaii's Plantation Village." Museum Worlds-Advances in Research, vol. 8, 2020, pp. 25-45.

-. "Portuguese in the Cane: The Racialization of Labour in Hawaiian Plantations." Changing Societies: Legacies and Challenges, vol. 1, edited by S. Aboim, P. Granjo, and A. Ramos, Imprensa de Ciências Sociais, 2018, pp. 65-96.

-. "Written in Stone, Cast in Iron: (Mis)Celebrations of Empire in LusoAmerican Encounters.” Conference Paper at the Ninth SIEF Conference, U of Ulster, Derry/Londonderry, 16-20 Jun. 2008.

-, Miguel Vale de Almeida, and Bela Feldman-Bianco, editors. Trânsitos coloniais: diálogos críticos luso-brasileiros. Imprensa de Ciências Sociais, 2002.

Bearak, Barry. "The Queen of Ethnic Nightmares; Cultural Politics Mires Statue of Borough's Namesake.” New York Times, 9 Jan. 1998, www.nytimes.com/1998/01/09/nyregion/queen-ethnic-nightmares-culturalpolitics-mires-statue-borough-s-namesake.html. 
Bethencourt, Francisco, and Kirti Chaudhuri. História da expansão portuguesa. Círculo de Leitores, 1999.

Bisram, Vishnu. "The Persecution of Portuguese (Madeirans-Azoreans) in PostIndependence Guyana.” As Mobilidades no Espaço e no Tempo: Madeira, Açores, Hawaii, Caribe, Centro de Estudos de História Atlântica Alberto Vieira, Funchal (Madeira), 14-15 Nov. 2019.

Bonyum, George R., "Report from Dr. Bonyum to the Governor of British Guiana.” Great Britain Parliament, House of Commons, Reports from the Commissioners, vol. 26, app. 18, 1848, pp. 62-65.

Borges, Marcelo J. Correntes de ouro: emigração portuguesa para a Argentina em perspectiva regional e transatlântica. Imprensa de Ciências Sociais, 2018.

Brand Flu, Cynthia. "Experiments with Indentured Labour, 1853-1866: The Portuguese from Madeira and their Descendants in Suriname.” Conference Paper at Slavery, Indentured Labour, Migration, Diaspora and Identity Formation, Paramaribo (Suriname), 18-23 Jun. 2018.

Brozan, Nadine. "Here's to Queen Catherine, Who Gave Queens a Name.” New York Times, 11 Oct. 1990, www.nytimes.com/1990/10/11/nyregion/here-sto-queen-catherine-who-gave-queens-a-name.html.

Carvalho, Clara, and João de Pina-Cabral. A persistência da história: passado e contemporaneidade em África. Imprensa de Ciências Sociais, 2004.

Castelo, Cláudia. Passagens para África: o povoamento de Angola e Moçambique com naturais da metrópole. Afrontamento, 2007.

-, Omar Ribeiro Thomaz, and Sebastião Nascimento, et al., editors. Os outros da colonização: ensaios sobre o colonialismo tardio em Moçambique. Imprensa de Ciências Sociais, 2012.

Cooper, Frederick, and Ann Laura Stoler, editors. Tensions of Empire: Colonial Cultures in a Bourgeois World. U of California P, 1997.

Davis, Natalie Zemon. "Regaining Jerusalem: Eschatology and Slavery in Jewish Colonization in Seventeeth-Century Suriname.” The Cambridge Journal of Postcolonial Literary Inquiry, vol. 3, no. 1, 2016, pp. 11-38.

Domingos, Nuno. Futebol e clonialismo: corpo e cultura popular em Moçambique. Imprensa de Ciências Sociais, 2012.

Drayton, Harold. An Accidental Life. Hansib, 2017. 
Drummond, Luís, Tito Noronha, Helena Correia, and Gregório Gouveia, “Testemunhos da Diáspora.” As Mobilidades no Espaço e no TempoMadeira, Açores, Hawaii, Caribe. Centro de Estudos de História Atlântica Alberto Vieira, Funchal, 14-15 Nov. 2019.

Ezratty, Harry A. 500 Years in the Jewish Caribbean: The Spanish and Portuguese Jews in the West Indies. Omni Arts, 2002.

Faculdade de Ciências Sociais e Humanas da U Nova de Lisboa. Counting Colonial Populations: Demography and the Use of Statistics in the Portuguese Empire, 1776-1890. 2020, colonialpopulations.fcsh.unl.pt/.

Feldman-Bianco, Bela. Saudade (Nostalgia). Documentary Educational Resources, 1991.

Fernandes, Gilberto. “'Oh Famous Race!' Imperial Heritage and Diasporic Memory in the Portuguese American Narrative of North America." The Public Historian, vol. 38, no. 1, 2016, pp. 18-47.

Ferreira, Jo-Ann S. "Madeiran Portuguese Migration to Guyana, St. Vincent, Antigua, and Trinidad: A Comparative Overview.” Portuguese Studies Review, vol. 14, no. 2, 2006, pp. 63-85.

Fried, Joseph P. “Catherine of Queens?” New York Times, 26 Jul. 1992, www.nytimes.com/1992/07/26/nyregion/catherine-of-queens.html.

Governo Geral da Província de Angola. "Mappa da população da província de Angola, por sexos e naturalidades, referido ao anno civil de 1899.” Annuario estatístico da província de Angola, Luanda, Imprensa Nacional, 1901, p. 3.

Gupta Pamila. "Blue Johannesburg: Post/Colonial Urban Infrastructure, Literature, and Culture.” Planned Violence, edited by Elleke Boehmer and Dominic Davies, Palgrave Macmillan, 2018, pp. 213-30.

Haynes, Henry Horatio. Letter (1851). Ministério dos Negócios Estrangeiros de Portugal, Arquivo Histórico Diplomático, Consulado Guiana Ingleza, box 700, ff. 74.

Henriques, Isabel Castro. Percursos da modernidade em Angola: dinâmicas comerciais e transformações sociais no século XIX. Instituto de Investigação Científica Tropical, 1997.

Hespanha, António. Filhos da terra: identidades mestiças nos confins da expansão portuguesa. Tinta-da-China, 2019. 
Holton, Kimberley Dacosta, and Andrea Klimt, editors. Community, Culture, and the Makings of Identity: Portuguese-Americans Along the Eastern Seaboard. Center for Portuguese Studies and Culture, 2009.

Hunter, Douglas. The Place of Stone: Dighton Rock and the Erasure of America's Indigenous Past. U of North Carolina P, 2017.

Jerónimo, Miguel Bandeira. The 'Civilising Mission' of Portuguese Colonialism, 1870-1930. Palgrave, 2015.

Kilgannon, Corey. “The Statue that Never Was.” New York Times, 9 Nov. 2017, www.nytimes.com/2017/11/09/nyregion/the-statue-that-never-was.html.

Leal, João. O culto do divino: migrações e transformações. Edições 70, 2017.

Lima, José Joaquim Lopes de. Ensaios sobre a statistica das possessões portuguezas, Lv. iii, parte i. Imprensa Nacional, 1846.

Lobo, Renata Lima. "Uma plantação de canas de açúcar no Campo das Cebolas para lembrar todos os escravizados.” Time Out, 2 Mar. 2020, www.timeout.pt/lisboa/pt/noticias/uma-plantacao-de-canas-de-acucar-nocampo-das-cebolas-para-lembrar-todos-os-escravizados-030220.

Margato, Cristina. "A controvérsia sobre um museu que ainda não existe: descobertas ou expansão?” Expresso, 12 Apr. 2018, expresso.pt/cultura/2018-04-12-A-controversia-sobre-um-Museu-queainda-nao-existe.-Descobertas-ou-Expansao-.

Matos, Patrícia Ferraz de. As "côres” do império. Imprensa de Ciências Sociais, 2006.

Mata, Inocência. A literatura africana e a teoria pós-colonial: reconversões. Nzila, 2007.

Medeiros, Carlos. A colonização das terras altas da Huíla (Angola). Centro de Estudos Geográficos, 1976.

Mello, Marcelo Moura. "Madeirans and Creole Labourers: Thinking Through Race and Labour in Post-Emancipation British Guiana.” Conference Paper at As Mobilidades no Espaço e no Tempo: Madeira, Açores, Hawaii, Caribe. Centro de Estudos de História Atlântica Alberto Vieira, Funchal (Madeira), 14-15 Nov. 2019.

Menezes, Mary Noel. Scenes from the History of the Portuguese in Guyana. Victoria, 1986.

Monteiro, José Pedro. Portugal e a questão do trabalho forçado: um império sob escrutínio (1944-1962). Edições 70, 2018. 
Mourier-Genout, Eric, and Michel Cahen. Imperial Migrations: Colonial Communities and Diaspora in the Portuguese World. Palgrave, 2012.

Newitt, Malyn. Emigration and the Sea. Hurst, 2015

Nóvoa, André. "Interviews about the Project of a Museum of Discoveries in Lisbon.” Portuguese Literary and Cultural Studies, 33, 2020, In Press.

O’Neill, Brian J. "Displaced Identities among the Malacca Portuguese." Recasting Culture and Space in Iberian Contexts, edited by Shawn Parkhurst and Sharon Roseman. State U of New York P, 2008, pp. 55-80.

Owen, Hilary, and Claire Williams. Transnational Portuguese Studies. Liverpool UP, 2020.

Pap, Leo. The Portuguese Americans. Twayne, 1981.

Ribeiro, Gladys Sabina. "Viagens e histórias de imigrantes portugueses na cidade do Rio de Janeiro na Primeira República.” Ler História, vol. 51, 2006, pp. 165-94.

Ribeiro, José Silvestre. Correspondência para o Ministério do Reino. Arquivo Regional da Madeira, liv. 644, 1846-1851.

Ribeiro, Margarida Calafate, and Ana Paula Ferreira, editors. Fantasmas e fantasias imperiais no imaginário português contemporâneo. Campo das Letras, 2003.

Roll, Elvira Osorio, Hawaii’s Kohala Breezes. Exposition, 1964.

Roque, Ricardo. “The Unruly Island: Colonialism's Predicament in Late Nineteenth-Century East Timor.” Portuguese Literary and Cultural Studies, vol. 17/18, 2010, pp. 303-30.

Sadler, Darlene J. The Portuguese-Speaking Diaspora. U of Texas P, 2016.

Salema, Isabel. "Kiluanji Kia Henda vence projecto para memorial às vítimas da escravatura.” $\quad O \quad$ Público, 2020 , www.publico.pt/2020/03/02/culturaipsilon/noticia/kiluanji-kia-hendavence-projecto-memorial-vitimas-escravatura-1906199.

Sanches, Manuela, editor. Portugal não é um país pequeno: contar o "império" na pós-colonialidade. Cotovia, 2006.

Santos, Boaventura Sousa. "Between Prospero and Caliban: Colonialism, Postcolonialism, and Inter-Identity.” Luzo-Brazilian Review, vol. 9, no.2, 2002, pp. 9-43.

Sarkissian, Margaret. D'Albuquerque's Children: Performing Tradition in Malaysia's Portuguese Settlement. U of Chicago P, 2000. 
Schomburgk, Robert H. Twelve Views of the Interior of Guiana, from Drawings Executed by Mr. Charles Bentley. Ackerman, 1841.

Silva, Manuel Luciano da. Os pioneiros portugueses e a Pedra de Dighton. Brasília, 1974.

Smith, M. Estellie. "Portuguese Enclaves: The Invisible Minority.” Social and Cultural Identity: Problems of Persistence and Change, edited by Thomas K. Fitzgerald. Southern Anthropological Society, 1974, pp. 81-91.

Sousa, António Teixeira de. Relatório e propostas de lei e documentos relativos às possessões ultramarinas. Imprensa Nacional, 1902.

Spranger, Ana Isabel, “Guiana Inglesa.” Dicionário enciclopédico aprender Madeira, 2014, aprenderamadeira.net/guiana-inglesa/.

Weir, Richard. "Neighborhood Report: Hunters Point Update-Update; Will a Queen Be Homeless?” New York Times, 13 Sept. 1998, www.nytimes.com/1998/09/13/nyregion/neighborhood-report-hunterspoint-update-update-will-a-queen-be-homeless.html.

Williams, Brackette F. Stains on My Name, War in My Veins: Guyana and the Politics of Cultural Struggle. Duke UP, 1991.

Xavier, Ângela Barreto. A invenção de Goa: poder imperial e conversões culturais nos séculos XVI e XVII. Imprensa de Ciências Sociais, 2008. 